\title{
BRITISH MAMMALS
}

\section{INTRODUCTORY NOTE}

\author{
By R. S. R. Fitter
}

For many years, in fact since the lamented demise of The Zoologist in 1916, the study of mammals in Great Britain has been greatly handicapped by the lack of a specialist journal. This deficiency it is now hoped to remedy by publishing in Oryx a regular section devoted to the natural history and conservation of British mammals. The twin aims of the section are well illustrated by the two articles in this first issue, one on the field study and identification of British bats, by Michael Blackmore, the other on the case for a close season for deer, by G. K. Whitehead, both among the leading experts in their respective fields. In addition it is hoped to publish regularly short notes on matters of general rather than local interest, to review books on or largely devoted to British mammals, and to abstract from local natural history journals any papers or notes of more than local interest. Editors of local journals, and secretaries of the mammal sections of local natural history societies and field clubs, could help this work greatly by sending me copies of their journals or reprints of any sections of articles relating to mammals. Address : Drifts, Chinnor Hill, Oxford.

The Bat Group.-Concurrently with the launching of the British Mammals section of Oryx, a number of naturalists specially interested in the study of bats have formed a Bat Group so that they can keep in touch with one another and exchange information. The Group's main objects will be to promote the study of bats in the British Isles and to undertake a full survey of their habits and distribution. Articles and short notes about bats by members of the Group will be included in each issue of the British Mammals section of Oryx; this section will thus virtually become the Group's journal. Members of the Bat Group who are already members of the Fauna Preservation Society will, of course, automatically receive Oryx. Other members of the Bat Group have the choice of either joining the Society, which it is hoped that many will do, or of subscribing 10s. 6d. per annum for Oryx. It is not proposed at present that members of the Bat Group should meet, but that they should correspond, either with Michael Blackmore (80 Nicholl House, 
Woodberry Down, London, N. 4) or with me. Subscriptions to Oryx will be handled by myself and material for inclusion should be sent to Michael Blackmore. Membership of the Bat Group is open to all those who take an interest in bats.

The Deer Group.-Shortly after the formation of the Bat Group another group of naturalists who are especially interested in the study of deer launched the Deer Group, with very similar aims and objects. The Deer Group's main aim is to enable people interested in deer in the British Isles to keep in touch with each other and to carry out a survey of their habits and distribution. Membership of the Group is open to all those who are interested in deer. Oryx will similarly act as the organ of the Deer Group, and each issue will contain articles and short notes on deer by members of the Group. It is hoped that members of the Group who are not already members of the Fauna Preservation Society will join; alternatively they can subscribe 10s. 6d. per annum for Oryx. Members of the Deer Group are invited to correspond either with G. K. Whitehead (The Old House, Withnell Fold, Chorley, Lancs), or with Gerald Johnstone (Oxford and Cambridge Club, Pall Mall, London, S.W. 1), or with me. Material for publication in Oryx should be sent in the first place either to G. K. Whitehead or to G. J. Johnstone and subscriptions to Oryx to me.

The Otter Investigation.-The formation of the Otter Committee in January, 1952, has already been briefly reported in these pages (Oryx, I, 2, 219), but a short recapitulation of its history and subsequent events may be of interest. The Home Office Committee on Cruelty to Wild Animals reported in 1951, and among other things recommended that there should be an inquiry into the natural history, and especially the feeding habits, of the otter, in view of the remarkable lack of information about its life history. Following a preliminary meeting under the auspices of the Universities Federation for Animal Welfare in December, 1951, the Otter Committee was formally set up on 23rd January, 1952, with Dr. E. Hindle, F.R.S., as chairman. A grant from the Nature Conservancy was successfully applied for, and in October, 1952, Miss Marie Stephens began work as the Committee's investigator. In 1953 the grant was renewed for a further year. It is hoped in a future issue of Oryx to give a brief account of the results of Miss Stephen's first year's researches. 